\title{
Subacute Combined Degeneration of the Cord: Putnam-Dana Syndrome
}

\author{
J.M.S. Pearce \\ Emeritus Consultant Neurologist, Department of Neurology, Hull Royal Infirmary, Hull, UK
}

\section{Key Words}

Subacute combined degeneration - Cobalamin •

Vitamin $\mathrm{B}_{12} \cdot$ Putnam-Dana syndrome

\begin{abstract}
The association of anaemia and gastro-intestinal abnormalities with disorders of the brain, spinal cord, and peripheral nerves has been recognized since the mid 19th century. In early reports interpretable as subacute combined degeneration, anaemia was overlooked, and conversely in Addison's and other early reports of pernicious anaemia, cord and nerve changes were not recorded. This paper shows that Lichtheim first combined the two observations, and illustrates the excellent descriptions in 1890 of James Putnam and Charles Dana. The most complete early account was that of Russell, Batten and Collier in 1900.
\end{abstract}

Copyright $\odot 2008$ S. Karger AG, Basel

The association of anaemia and neurological abnormalities with disorders of the brain, spinal cord, and peripheral nerves has been recognized in many clinical and post-mortem case reports [1, 2]. James Combe [3] of Edinburgh is uncertainly credited with the earliest description of pernicious anaemia (PA), but no unequivocal diagnostic features of PA or subacute combined degeneration of the cord (SACD) are evident.

It was not until Thomas Addison [4-6] provided a clinicopathological description that PA was recognized as a distinct entity, which Trousseau named 'Addisonian anaemia'. Addison, and later Fenwick [7, 8], described anaemia, debility and gastric atrophy. Unlike other anaemias then known, it was almost always fatal. Addison's account is found in his introduction to 'Disease of the suprarenal capsules', but he describes neither neural symptoms nor changes in the cord or nerves. Biermer [9] also described and used the name pernicious anaemia in 1872 but he recorded no neurological signs. Paul Ehrlich in 1880 initiated the term megaloblast to describe the large cells in the bone marrow in PA. Leichtenstein [10], in 1884, reported the first clear association of PA and spinal cord disease, but attributed it to tabes dorsalis. Gowers [11, 12] described 'ataxic paraplegia - combined lateral and posterior sclerosis' with a detailed clinicopathological account that included sphincter involvement; he distinguished it from tabes dorsalis, but did not mention anaemia. Lichtheim [13] deserves credit for recognizing the combination of cord degeneration with PA in 1887. He noted that the histology of the cord in tabes was distinctly different from that found in PA.

William Hunter [14], in 1900, recorded several distinctive cases of SACD in PA in one of three lengthy papers that were dominated by the causal role of oral and dental infections. Russell et al. [15] reported the definitive clinical analysis of subacute combined degeneration in 1900 , which has not been bettered. In respect of anaemia they noted:

\section{KARGER}

Fax +41 613061234 E-Mail karger@karger.ch www.karger.com

\section{(C) 2008 S. Karger AG, Base \\ 0014-3022/08/0601-0053\$24.50/0}

Accessible online at:

www.karger.com/ene
J.M.S. Pearce

304 Beverley Road

Anlaby, East Yorks, HU10 7BG (UK) 


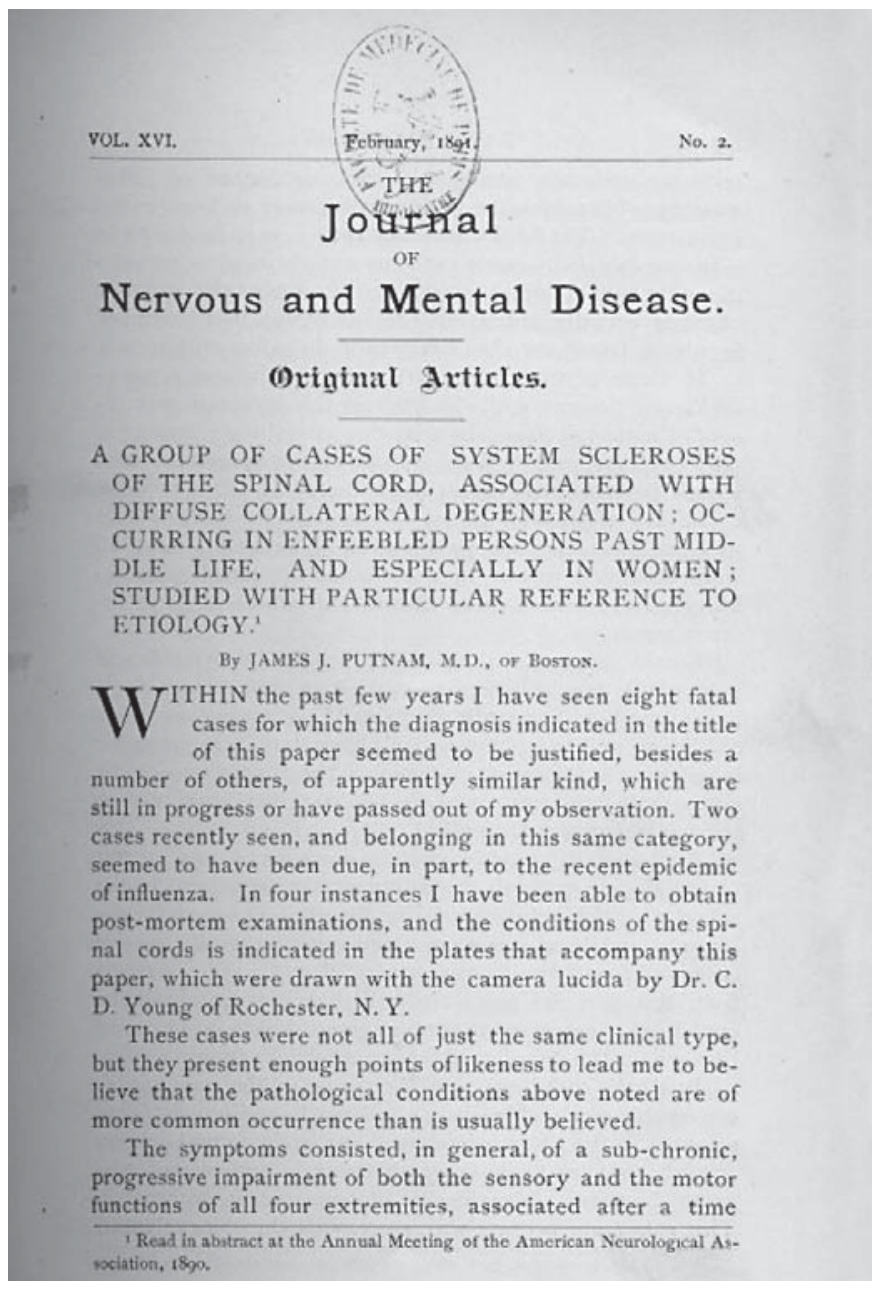

Fig. 1. Putnam's introductory comments, 1891. From [18].

'... Some of the most typical cases presented no anaemia throughout the course ... others only late in the disease, while in other cases anaemia was an obtrusive symptom from the first and preceded the nervous symptoms by many months.'

\section{They also noted that nomenclature was a problem:}

'A name other than "combined degeneration" would undoubtedly do much to establish the affection as a distinct morbid entity, ... in consequence of the fact that so many different diseases of the spinal cord are characterised by combined degeneration of tracts of different function.'

\section{Kinnier Wilson [16] also remarked that:}

'the lesions are neither confined to the dorsal and lateral columns nor systematized; the term conveys no hint of the connexion with anaemia; the epithet "subacute" is not only awkward to define, but inapplicable at least to some instances ...'
The diagnosis of these mixed and irregular types such I have reported and which I believe to be not infreas 1 hent, of course, rests on the recognition of sensory quent motor symptoms, together with some sign (such as exaggerated knee-jerk or ankle-clonus, paralysis as exaggerated kne symptoms are of spinal origin. Where it happens that the symptoms are of spinal origin. kinds, associated with a moderate amount of motor weakness and some impairment of electrical irritability, and as ness and some impairment of electrical irritability, and as in Case III. and of the Appendix, 1 know of nowritis, and it is ing the diagnosis of chronic generalized neuritis, and it is not impossible that, as ${ }^{*}$ in locomotor ataxia, more or less

Fig. 2. Putnam on diagnosis. From [18].

\section{Subacute Combined Degeneration and Anaemia}

But who first recognized SACD and its link with PA? An early contender was Lichtheim and his pupil Minnich [17], who in 1892 described 2 patients with PA who had cord involvement and at autopsy demonstrated changes especially in the posterior columns. However, earlier in 1890, Putnam [18] reported 8 'enfeebled patients' (7 women, 1 man) with combined sclerosis of the corticospinal tracts and posterior columns, and neuritis; in addition, they suffered from anaemia and exhaustion. Curiously, he included sphincteric paralysis, which is usually absent or of late occurrence. Part of his description [18] from a long and comprehensive paper is shown in figures 1 and 2. Putnam recorded:

'A group of cases of systemic scleroses of the spinal cord, associated with diffuse collateral degeneration; occurring in enfeebled persons past middle life, and especially in women.'

He noted the diagnostic importance of corticospinal signs of clonus and incoordination, and stressed:

'the progressive impairment of both the sensory and the motor functions of all four extremities.'

Charles Loomis Dana (1852-1935), Professor of Nervous Diseases at the Cornell Medical School, in the same year as Putnam, described a case of severe anaemia and cord degeneration, which he called 'a new type' [19]. In 1899 , he amplified this account, naming it 'subacute combined sclerosis of the spinal cord'; he related it to anaemia [20]. Born in Woodstock, Vt., USA, Dana qualified at Columbia University College of Physicians and Surgeons and helped to found the New York Neurological Institute in 1909. He was President of the American Neurological 
Association as well as a distinguished classicist and authority on Horace. Although SACD is often referred to as 'Putnam-Dana syndrome', Dana [21] perhaps enjoyed less celebrity than Putnam. His textbook Treatise on Nervous Diseases went through nine editions.

James Jackson Putnam (1846-1918) was born in Boston of distinguished New England ancestry. His father was a respected physician in Boston, and his grandfather was Judge of the Supreme Court of the State of Massachusetts. His maternal grandfather, who married a Cabot, was Dr. James Jackson, a notable medical figure of his time. Putnam graduated at Harvard in 1866. He continued his education at Leipzig, Vienna, Paris, and London, working with von Rokitansky, Meynert and Hughlings Jackson. He returned to Harvard, and in 1893 became Professor of Neurology, until his retirement in 1912. Putnam was one of the seven founders of the American Neurology Association and was its president in 1888 . He became increasingly interested in the treatment of psychoneurosis and psychoanalysis and used his influence to persuade Freud to visit the United States in 1907. Putnam turned to religious, social and ethical questions and published Addresses on psychoanalysis (London and $\mathrm{New}$ York, 1921). Apart from his many contributions to neuropathology and neurology, he was one of the first to observe that hyperthyroidism may evolve into hypothyroidism, long before autoimmune mechanisms were understood. He was one of the earliest to study disorders of the basal ganglia. Putnam was perhaps the first in the chain of brilliant Harvard neurologists (Putnam, Stanley Cobb, Raymond Adams, Derek Denny Brown, Miller Fisher) who dominated 20th century American neurology.

\section{Pernicious Anaemia}

PA is an autoimmune disorder characterized by autoantibodies to gastric parietal cells or intrinsic factor. Patients have gastric atrophy and frequently associated thyroiditis and myxoedema. Cobalamin deficiency [22] causes an accumulation of homocysteine and methylma- lonic acid. Dysfunction of the methyl transfer pathway may be the cause, but precisely how it causes subacute combined degeneration is uncertain [23]. Anaemia and macrocytosis are absent at presentation in one third of patients with SACD [24]. Apart from PA, there are many other well-documented, but less common causes of cobalamin deficiency.

Traditionally, four types of neurological dysfunction occur: (1) dementia or psychotic symptoms, (2) optic neuropathy, (3) peripheral nerve and posterior columns symptoms and (4) lateral column (spastic) symptoms [25, 26]. Cervical and thoracic hyperintensity in the posterior and lateral columns on $\mathrm{T}_{2}$-weighted MRI images, mainly due to demyelination, are characteristic.

\section{Liver Factor and Vitamin $\mathrm{B}_{12}$}

At a meeting of the Association of American Physicians in Boston on May 4, 1926, Minot and Murphy [27] described their results in 45 patients with PA given a high protein diet for between 6 weeks and 2 years. Their daily diet contained 120-240 g of liver and $120 \mathrm{~g}$ of muscle meat that caused rapid symptomatic improvement, and increased the erythrocyte count. They called this the 'liver factor' which saved many lives. With George Whipple, they received the Nobel Prize in 1934 'in recognition of their discoveries respecting liver therapy in anaemias'. William Castle [28] discovered gastric 'intrinsic factor' essential for cobalamin absorption in 1930. 1948 saw the isolation of anti-PA factor from the liver and kidney by Smith [29], and by Rickes et al. [30] who named it vitamin $\mathrm{B}_{12}$. Dorothy Hodgkin [31] used X-ray crystallography to disclose its structure for which she, too, received the Nobel Prize of 1956. After cobalamin replacement, half make a complete recovery; the extent of residual disability relates to the severity of signs before treatment and the duration of symptoms [24]. Folic acid supplements are dangerous since they can reverse megaloblastic anaemia caused by $\mathrm{B}_{12}$ deficiency, but neurological degeneration may progress unabated.
References

Putnam-Dana Syndrome
4 Addison T: Anaemia: disease of the suprarenal capsules. London Med Gazette 1849;8: 517-518.

5 Addison T: On the Constitutional and Local Effects of Disease of the Supra-Renal Capsules. London, Highley, 1855. Reprint London, New Sydenham Society, 1868, p 211.
3 Combe JJ: History of a case of anaemia. Trans Med Chir Soc Edinb 1822;1:194-204.
Russell JSR, Batten FE, Collier J: Subacute combined degeneration of the spinal cord Brain 1900;23:39-110.

-2 Pearce JMS: A classic description of subacute Pearce MS. A classic description of subacute 
6 Major RH: Classic Descriptions of Disease, ed 3. Springfield, Thomas, 1965, pp 290294.

7 Fenwick S: On atrophy of the stomach. Lancet 1870;ii:78-80.

8 Fenwick S: On Atrophy of the Stomach and on the Nervous Affections of the Digestive Organs. London, Churchill, 1880.

9 Biermer MA: Eine eigenthümliche Form von progressiver perniciöser Anaemie, Correspondenz - Blatt 4. Schweiz Arzte 1872;2: 15-18.

10 Leichtenstein O: Über progressive perniciöse Anämie bei Tabeskranken. Dtsch Med Wochenschr 1884;10:849.

11 Gowers WR: Manual of Diseases of the Nervous System. London, Churchill, 1886, vol 1, pp 341-348.

12 Gowers W: Ataxic paraplegia. Lancet 1880;ii:618.

13 Lichtheim L: Zur Kenntnis der perniziösen Anämie. Schweiz Med Wochenschr 1887;34: 300.

14 Hunter W: Further observations on pernicious anaemia (seven cases): a chronic infective disease. Lancet 1900;i:221-225.

15 Russell JSR, Batten FE, Collier J: Subacute combined degeneration of the spinal cord. Brain 1900;23:39-110.
16 Wilson SAK: Neurology. London, Arnold, 1940, vol 2, pp 1339-1340.

17 Minnich W: Zur Kenntnis der im Verlauf dr perniciösen Anämie beobachteten SpinalErkrankungen. Ztschr Klin Med 1893;21: 25-60, 264-314; cited by Haden RL: Pernicious anemia from Addison to folic acid. Blood 1948;3:22-31.

18 Putnam JJ: A group of cases of system scleroses of the spinal cord, associated with diffuse collateral degeneration; occurring in enfeebled persons past middle-life, and especially women; studied with particular reference to etiology. J Nerv Ment Dis 1891;16:69-110.

19 Dana CL: The degenerative diseases of the spinal cord, with the description of a new type. J Nerv Ment Dis 1891;18:205-216.

20 Dana CL: Subacute combined sclerosis of the spinal cord and its relation to anemia and to toxemia. J Nerv Ment Dis 1899;26:1.

21 Peterson F: Charles Loomis Dana. Science 1935;82:607-608.

22 Richmond J, Davidson S: Subacute combined degeneration of the spinal cord in nonAddisonian megaloblastic anaemia. Q J Med 1958;27:517-631.

23 Fritschi J, Sturzenegger M: Spinal MRI supporting myelopathic origin of early symptoms in unsuspected cobalamin deficiency. Eur Neurol 2003;49:146-150.
24 Healton EB, Savage DG, Brust JC, Garrett TJ, Lindenbaum J: Neurologic aspects of cobalamin deficiency. Medicine (Baltimore) 1991; 70:229-245.

25 Ropper AH, Brown RH: Adams and Victor's Principles of Neurology. Part 5. Diseases of Spinal Cord, Peripheral Nerve, and Muscle, ed 8. New York, McGraw-Hill, 2005.

26 Rundles RW: Prognosis in the neurologic manifestations of pernicious anemia. Blood 1946;1:209-219.

27 Minot GR, Murphy WP: Treatment of pernicious anemia by a special diet. JAMA 1926; 87:470-476.

28 Castle WB, Townsend WC, Heath CW: Observation on the etiologic relationship of achylia gastrica to pernicious anaemia. Part 3. Am J Med Sci 1930;180:305-335.

29 Smith EL: Purification of anti-pernicious anaemia factors from liver. Nature 1948;161: 638-639.

30 Rickes EL, Brink NG, Koniuszy FE, Wood TR, Folkers K: Crystalline vitamin B12. Science 1948;107:396-397.

31 Hodgkin DC, Camper J, Mackay M, Pickworth J, Trueblood TKM, White JG: Structure of vitamin $B_{12}$. Nature 1956;178:64-66. 